\title{
How can the land managers and his multi-stakeholder network at the farm level influence the multifunctional transitions pathways?
}

\author{
Filipe Barroso, Helena Menezes e Teresa Pinto Correia
}

Abstract: The changing role of agriculture is at the core of transition pathways in many rural areas. Productivism, post-productivism and multifunctionality have been targeted towards a possible conceptualization of the transition happening in rural areas. The factors of change, including productivist and post-productivist trends, are combined in various ways and have gone in quite diverse directions and intensities, in individual regions and localities. Even, in the same holding, productivist and postproductivist strategies can co-exist spatially, temporally, structurally, leading to a higher complexity in changing patterns. In south Portugal extensive landscapes, dominated by traditionally managed agroforestry systems under a fuzzy land use pattern, multifunctionality at the farm level is indeed conducted by different stakeholders whose interests may or not converge: a multifunctional land management may indeed incorporate post-productivist and productivist agents. These stakeholders act under different levels of ownership, management and use, reflecting a particular land management dynamic, in which different interests may exist, from commercial production to a variety of other functions (hunting, beekeeping, subsistence farming, etc.), influencing management at the farm level and its supposed transition trajectory. This multistakeholder dynamic is composed by the main land-manager (the one who takes the main decisions), sub land-managers (land-managers under the rules of the main land-manager), workers and users (locals or outsiders), whose interest and action within the holding may vary differently according to future (policy, market, etc.) trends, and therefore reflect more or less resilient systems. The goal of the proposed presentation is to describe the multi-stakeholder relations at the farm level, its spatial expression and the factors influencing the land management system resilience in face of the transition trends in place.

Keywords; land managers; multi-stakeholders network; multifunctional transitions pathways;

DOI: http://dx.doi.org/10.5261/2013.GEN4.04

Citação: Barroso, F., Menezes, H., and Pinto-Correia, T., 2013, How can the land managers and his multistakeholder network at the farm level influence the multifunctional transitions pathways? Spanish Journal of Rural Development 4(4): 35-48. http://dx.doi.org/10.5261/2013.GEN4.04 